\title{
BROKERS AND MIDDLEMEN IN INDONESIAN HISTORY: A REVIEW
}

\author{
Audrey R. Kahin
}

The Third Dutch-Indonesian Historical Conference, ${ }^{1}$ held in 1980, had two major themes, "The Historiography of Indonesia 1945-1979" and "Middlemen in Indonesia in the Period of Dutch Colonialism"--a topic that commanded the attention of fifteen of the twenty-one contributing participants. The authors who wrote on Indonesian historiography were in fact little concerned with Indonesia's history after 1950 and most of their articles (four out of six) ${ }^{2}$ dealt with the nationalist movement and the revolution. In effect, then, the majority of the papers making up the present volume focus on two sides of colonial rule that have attracted considerable attention from historians of Southeast Asia over the past two decades: the history of the anticolonial struggle, and the mediating role played by certain individuals and groups between the indigenous societies and the colonial power.

The early papers on historiography ${ }^{3}$ provide competent surveys of some of the postwar studies of Indonesia's independence struggle, but offer few new insights. While they point up some of the failings in Western approaches and in Indonesian "nationalist" historiography, they add little of substance to the ongoing debate. As two of the authors conclude after a brief survey of the literature on the revolution: "if we .. . feel with Sukarno that the revolution was more than just a war of national independence, we have to come up with something more than the quotationmark revolutions, or else we might just as well say that the Indonesian revolution was multi-complex and thereby save ourselves a lot of breath." 4 Unfortunately, we get none of the reactions from the participants to this or any other statements in the papers.

Introducing the principal theme, Dr. Kuitenbrouwer, in his stimulating essay, "The Concept of Middleman and the Study of Indonesian History," acknowledges the historian's debt to those anthropologists who have pioneered research on brokers

1. Papers of the Dutch-Indonesian Historical Conference Held at Lage Vuursche, The Netherlands 23-27 June 1980, ed. Gerrit Schutte and Heather Sutherland (Leiden/Jakarta: Bureau of Indonesian Studies under the auspices of the Dutch and Indonesian Steering Committees of the Indonesian Studies Programme, 1982). All page numbers appearing in parentheses in the text refer to this volume.

2. The other two were "Priangan Historiography," by Dr. Edi S. Ekadjati; and "Priests, Popes and Penghulu's: A Review of Dutch Names for Indonesian Muslim Leaders," by K. Steenbrink.

3. "Nation-Formation and Structural Concern: A Problem in Indonesian Historiography," by Taufik Abdullah; "Historiography on the Revolution: The Western Approach," by J. Bank; "The Historiography on the Indonesian Revolution: Some Remarks on Western Approaches," by W. E. J. Remmelink and Jang A. Mutallib; and "Some Remarks on Indonesian Nationalist Historiography," by H. A. J. Klooster.

4. Remmelink and Mutallib, "Historiography on the Indonesian Revolution," p. 44. 
and other categories of middlemen. Arguing against historians getting overly bogged down in the minutiae of role differentiation, particularly between the broker and the mediator, however, he contends that historical research "should start with the inclusive but more provisional concept of middleman, that takes into account the variety of roles mediating between and within social networks, leaving room for a further elaboration of terms as far as the results of the research will justify" ( $p$. 101). 5

One can readily concede the utility of a term that can encompass not merely the primarily economic function of the broker, but also the range of political, administrative, and social interaction between the societies making up the Dutch East Indies. Certainly the topics of the papers presented at this conference embrace a wide variety of intermediary roles, from those played by individual merchant adventurers who bridged the gap between the distant government in Batavia and the local rulers, particularly of eastern Indonesia, to that of the regents on Java who collectively constituted the lynchpin of the Dutch ability to rule that island. But being used so broadly, one suspects, the term can easily overflow all useful limits. (For instance, it could be stretched to view the VOC or its successor NEI administration as "middlemen" between the colony and homeland, but it is difficult to perceive the value of such an approach.)

Suspicion that the elasticity of the concept as employed here tends to rob it of meaning seems to be borne out in a number of the papers, where their authors' research and writing were clearly undertaken within a different framework of analysis, and the necessary phrases tying the body of the essay to the middleman theme have been imposed somewhat arbitrarily and unconvincingly at the beginning and end. As one of the editors, G. J. Schutte, acknowledges in his Foreword to the volume: "this heading served as an umbrella for an embarrassing richness of subjects, varying not only in the nature and place of the proffered mediation, but also in the definition of middlemenship and brokerage as applied and tested in the papers." Though the fluidity of categorization does tend to undermine the thematic coherence of the papers, however, such a situation is by no means unusual in conferences and collections, so this particular volume should not be too severely criticized on this account.

In an effort to provide a more concrete and specific definition of the middleman's role, Heather Sutherland ${ }^{6}$ is in accord with the general proposition that he forms a bridge between two sides, providing "the means of access by which one group can try to obtain what it wants from another." She argues, however, that, to be effective, he must be more than this: "he must be involved, he must be central to the process of interaction. A passive peripheral intermediate figure is no middleman" (p. 252). F. A. Gaastra's views ${ }^{7}$ are in harmony with this when he contends that "Mediators and middlemen are indispensable for the colonial powers, and this fact gives them a power of their own, a power that originates from their very role of mediators" ( $p$. 302). Taufik Abdullah in a paper to an earlier Dutch-

5. He recognizes that the extremely close interaction of colonial government, economic enterprise, and Javanese society in the late nineteenth century meant that "middlemen easily turned into brokers."

6. In her paper, "Mestizos as Middlemen? Ethnicity and Access in Colonial Macassar."

7. In his paper, "Merchants, Middlemen and Money: Aspects of the Trade between the Indonesian Archipelago and Manila in the 17th Century." 
Indonesian historical conference ${ }^{8}$ went further in defining the active role of these intermediary figures, when he put forward the concept of the links connecting the Dutch and Indonesian worlds as themselves crystallizing into a more elaborate "schakel-society"-_an artificial society, "a world of pretense" that created its own realities, "a theatre where both the ruler and the ruled played their roles while maintaining their separate sense of reality." 9 This schakel society served "as a channel through which the two strange worlds shared something without endangering their respective basic cultural assumptions."

But in referring to this characterization of the interaction, Kuitenbrouwer stresses that the schakels were usually firmly lodged in one or other of the two strange worlds, for, he states, "apart from the Chinese, there generally existed no independent landowning or commercial elite within Indonesian society." The Indonesians who worked as part of the Dutch system of administration, then, "were initially also the most important patrons within their own communities" ( $p$. 105). Thus the brokerage and patronage phenomena overlap, and in separating them Kuitenbrouwer accepts the distinction drawn by J. Breman, ${ }^{10}$ and applies the term patronage to closed rural societies in the early stages of modernization, and brokerage to the "more specialized mediating role, originating from the increasing interference of outside political and economic forces in the village sphere" $(p .100)$. This seems a more accurate and useful approach, certainly with respect to Indonesian society, than extending the patronage model to cover many relationships in colonial and postcolonial Indonesia for which it is often inappropriate. ${ }^{11}$

However loosely the term is applied, the role of the middleman is a potentially fruitful starting point from which to analyze the nature of colonial rule in Indonesia. The key element is the dynamic and changing character of this role--whether carried out by broker, adventurer, administrative class, racial minority, or religious group--all of whom appear under the guise of middleman in this volume. By isolating the nature and function of this intermediary, it becomes possible to perceive with greater clarity the changing shapes of the societies between which the individual or group mediated, and evaluate and assess with more precision the evolution of colonial rule, and the relative weaknesses or strengths of the rulers and the ruled. ${ }^{12}$

8. Taufik Abdullah, "The Beginning of the Padri Movement," in Papers of the Dutch-Indonesian Historical Conference Held at Noordwijkerhout. The Netherlands, 19 to 22 May 1976 (Leiden/Jakarta: Bureau of Indonesian Studies, 1978), pp. 143-53.

9. Ibid., p. 148.

10. J. Breman, "Over Oude en nieuwe afhankelijkheidsrelaties. De maatschappelijke context van patronage en makelaardij," in Buiten de Grenzen (Meppel: Boom, 1971), pp. 31-46.

11. Cf. James C. Scott, "Patron-Client Politics and Political Change in Southeast Asia," American Political Science Review, 66 (1972), pp. 91-113.

12. Clifford Geertz, of course, more than twenty years ago recommended using the study of the broker, in a similar way, in trying to understand the Indonesia of the 1950s: "Focussing on the connection between the local and national levels of sociocultural integration, rather than exclusively on the one or the other, can bring out more clearly what the process of nation-building in the new countries of Asia and Africa involves. In Indonesia political party leaders, small town professionals, and many other sorts of roles from this point of view could go far toward estimating the possibilities for effective national integration in that still incompletely unified country, and perhaps even offer clues as to the shape that integration will finally 
To attempt such analysis it is necessary to delineate the peripheries of the societies for which the middleman provided the link--the terrain where these societies overlapped, thus providing his basis of operations. This meeting ground was different in different times and different places. Furnivall's analysis of the "plural society," as Heather Sutherland reminds us, depicted the interaction between the different elements as "in the strictest sense a medley, for they mix but do not combine. Each group holds by its own religion, its own culture and language, its own ideas and ways. As individuals they meet, but only in the market place." 13 She contends, however, that this was not the case in "the real, dynamic and multiethnic world of Makassar," which presented a picture not "of a horizontally stratified racial society, but of various communities running parallel along a vertical axis, with the elites of all races in close contact with each other" (p. 251). Thus far, her analysis of eighteenth century Makassar accords with Lijphart's portrayal of the "pillars" of twentieth century Dutch society, ${ }^{14}$ but whereas in the Netherlands interaction only occurred at the very apex, Makassar, according to Sutherland, "was characterized by considerable economic and social interaction, on an equal footing between local chiefs and merchants, Chinese, mestizos and Europeans," and this interaction was "also true of the lower levels of the society." All groups "traded together, plotted together, and made and lost money together" ( $p$. 251).

Such a portrait of eighteenth century Makassar can be set beside van Doorn's description of the development of the plural colonial society, ${ }^{15}$ and the distinction he draws between the character of the old and modern colonial cities: "The older a colonial city . . . the more pronounced the degree of intermixture within the population. Modern colonial cities, in contrast, were marked by a pronounced stratification; Indonesians, Indo-Europeans, totoks and Chinese not only could be distinguished in terms of settlement patterns, but also by their mutually different and partially conflicting interests" $(p .150)$. He argues that, despite "tendencies in late-colonial Indonesia pointing toward integration and assimilation," the processes of modernization, rather than encouraging assimilation in fact increased the social segmentation, with "their ultimate function .. . primarily an integration of the segments within the population" ( $p .155$, emphasis in the original).

Attempts in this volume and elsewhere to compare the Indies in colonial times with a segmented or "pillar" society have of necessity to exclude its Dutch elements who never formed the base of any pillar. Individuals or smaller groups of Dutchmen might rank below the top level of the indigenous hierarchy--with the lowest Dutch colonial officials subordinate to the regent, sultan, or sometimes wedana, but even they were not markedly inferior, and had a support apparatus on which they could call that would obviate any disadvantage in terms of personal status. Other than (arguably) in a few urban areas, then, the pillar terminology can only be reliably used to delineate the lines of the indigenous, highly autonomous societies in many areas of the outer islands where the long contract was in operation. In these the Dutch relied on indirect rule, and the self-contained local societies communicated

take." "The Javanese Kijaji: The Changing Role of a Cultural Broker," Comparative Studies in Society and History, 2, 2 (January 1960), p. 249.

13. J. S. Furnivall, Colonial Policy and Practice (Cambridge: Cambridge University Press, 1948), p. 304.

14. See, for example, Arend Lijphart, "Consociational Democracy," World Politics, 21, 2 (January 1969), pp. 207-25.

15. J. J. A. van Doorn, "A Divided Society: Segmentation and Mediation in LateColonial Indonesia." 
with one another largely through their own ruling elites. (Trade and the market place, however, were certainly other places where connections were established between the communities.) More closely approximating the actual shape of the coexisting Dutch and indigenous hierarchies in the late nineteenth century, it seems to me, at least in the administrative sphere, would be a disjointed vertical line, with the lowest of the Dutch officials providing the link with the highest indigenous official. Below the levels at which this link was effected, the indigenous societies maintained their diverse patterns, often decisively altered from the precolonial forms by the nature of the pressure exercised by the Dutch.

The level of the indigenous hierarchy at which the link with the Dutch was established varied in accordance with the region and the nature of Dutch rule there at different periods--from the sultans in areas of indirect rule in the outer islands," 16 to the regent in nineteenth century Java, to the village heads in plantation areas and certain village-based societies. (Unfortunately, none of the papers focuses on the role of these village heads, and only in Kuitenbrouwer's introductory remarks is mention made of their efforts "to incite the antagonism between colonial government and European planters in order to increase their own room for maneuver" I $p$. 111].) P. J. Drooglever, who is specifically concerned with the civil service, ${ }^{17}$ has for 1900 pinpointed the link on Java at the district level, where "controleur and wedono together, sometimes nicknamed the walking twins, by then were the main mediators or middlemen between Java and the Dutch" $(p .198)$. He sees these mediators gradually superseded by institutions as, during the years from 1900 to 1930, the administration was decentralized and many of the tasks it had previously performed were now carried out by officials of technical departments and services. As the nature of the civil service changed, professional organizations increasingly came to represent the interests of the individual officials vis-à-vis the higher Dutch administrators. Decentralization also meant that regency councils were given a larger role to play in district government, and Drooglever notes that one result of this was that the regent regained some of the standing he had lost to the wedana in the late nineteenth century as the latter had risen by virtue of his higher educational qualifications. During the closing years of colonial rule on Java, the regent's position at the head of the regency council also strengthened him in his relationship with his Dutch counterpart. ${ }^{18}$

Consistent with Drooglever's analysis of the nature of the changes occurring in the colonial administration, van Doorn notes that among the Indo-Europeans and other racial minorities the closing years of colonial rule saw institutions progressively assuming the intermediary roles earlier performed by individuals. He recognizes, however, that the narrow field to which these institutions were confined usually prevented their fulfilling any meaningful mediating function.

It was in the economic field that more meaningful interaction took place among the societies of the Indies, with both individuals and racial minorities frequently playing the intermediary role. Several papers in the volume are concerned with individual entrepreneurs, the middlemen par excellence, whose livelihood depended on their ability to exploit the economic opportunities existing at the margins of the

16. None of the papers deals with this level of the indigenous hierarchy. The closest is the paper of Nazaruddin Syamsuddin on "The Ulama, the Ulebalang and the National Revolution in Aceh."

17. "The Civil Service as Mediator in Late-Colonial Java."

18. Focusing on the regents' efforts "to realize mutually contradictory values" is the paper of Sartono Kartodirdjo. "The Regents in Java as Middlemen: A Symbolic Action Approach." 
different communities and whose lives frequently depended on their success. Among them we find the Arab, Said Abdullah, 19 "krissed by order of the raja of Lombok" in 1891 (p. 223), the Dutch resident of Saparua, Lambertus Schmit de Haart, accused of embezzling government funds and participating in the slave trade in the Central Moluccas in the early nineteenth century, ${ }^{20}$ and Mads Lange, the Danish trader, ${ }^{21}$ whose factory in southern Bali "formed a vital hinge between inter-Asiatic trade and the inland Balinese economy," and who acted as an important agent for the Dutch and an indispensable part of the power of raja Kesiman of Badung. All these narratives ${ }^{22}$ provide interesting sidelights on the nature and fragility of the Dutch relationship with some of the societies of the Indies.

With regard to the racial minorities, Sutherland argues that in Makassar it was their trading function rather than their ethnicity as such that enabled the mestizos to act as middlemen between the European and indigenous societies. Their business operations were crucial to their leverage, providing them with a position from which they could establish liaisons with both the leaders of Dutch society and the sultans' families of South Sulawesi. When their trading role declined, so too did their ability to "organise the interaction between political elites of two races, " although in twentieth century Makassar she suggests that they were still fulfilling a "middleman" role, but now "between a bureaucratic political center and a peasant population" (p. 270).

Syamsuddin in his article on the Malays in Bima ${ }^{23}$ is less concerned with their intermediary role than with the early history of the Islamization of the island. Nevertheless, he does follow the history of the descendants of ulama from Sumatra who originally converted the people of Bima to Islam in the early seventeenth century and came to form a special, largely segregated Malay community with special trading rights and privileges. They acted not only as middlemen between Bimanese and Dutch through the medium of the Malay language, but also between Bimanese and other indigenous groups of the Indies.

Ong Hokham ${ }^{24}$ focuses on nineteenth century Java and the peranakan Chinese role not only as farmers of government revenues, particularly opium, but also as officers for the totok Chinese communities, and intermediaries between them and the Dutch. Their middleman role came to an end when the government abolished the auctioning of revenue farms and with the arrival of large numbers of totok Chinese with whom the peranakan could not communicate. Unfortunately, the author does not indicate who took their place as intermediaries between the Dutch and these newly arrived Chinese. The interest of his article lies less in the peranakans' middleman role than in the histories he narrates of individual peranakan families.

19. In J. van Goor, "The Death of a Middleman: Scheming in the Margin of the Dutch East Indies."

20. R. Z. Leirissa, "Lambertus Schmit De Haart, Resident of Saparua 1817-1823."

21. H. G. Schulte Nordholt's paper, "The Mads Lange Connection: A Danish Trader on Bali in the Middle of the Nineteenth Century: Broker and Buffer," was published separately in Indonesia, 32 (October 1981), pp. 16-47.

22. One paper on the margin of this group is that of Mona Lohanda, "Majoor Jantje and the Indisch Element in Betawi Folkmusic."

23. Helius Syamsuddin, "The Coming of Islam and the Role of the Malays as Middlemen on Bima."

24. "The Peranakan Officers' Families in Nineteenth Century Java." 
Luckman Sinar ${ }^{25}$ portrays the Chinese community in East Sumatra rising from coolie status, through roles as trader and smallholder, to a current position as wealthy magnates and industrialists. In his view, "nearly 75\% of all kinds of industries in East Sumatra are fully or partially owned by . . . Indonesian citizens of Chinese origin ... [and] nearly 99.99\% of shops with all kinds of trades" (p. 356). One would imagine that this latter figure at least must be something of an exaggeration.

The title of the conference restricted its theme to the role of middlemen in the colonial era and most of the authors did focus on the years before 1942 when clearer demarcation lines made the middleman and his operations easier to isolate. One of the few to give primary emphasis to postindependence Indonesia is the paper of $H$. de Jonge, ${ }^{26}$ but it is one of the most interesting. In it the author examines the trading network operating between the tobacco growers on Madura and the entrepreneurs and manufacturers on Java and Bali. The article is principally concerned with a village where the Chinese were ousted from their role of entrepreneur in about 1913 after the establishment of the Sarekat Islam, and which subsequently became one of the most important trading communities in the region. The ten wealthy traders (juragan) who now link the Madura network with the Javanese manufacturers have close family ties with one another, have all made the haj, and "adhere to the modernist interpretation of Islam." Though during the recent years of the New Order, they have become less active politically, "Yet behind the scenes they still exert tremendous influence. They succeed in keeping friends with both the Madurese officials, supporters of Suharto's Golkar, and the religious leaders on the island" ( $p .325$ ). The author sees little change in the structure of the network over recent years or in the ties between these juragan, their subordinate small suppliers (bandol), and the bandol's local contacts (bandol keneq). The relationships between the components do not alter, and there is no upward mobility or exchange of roles.

The conference's two themes gave the papers a focus often lacking in collections of this type. Particularly on the topic of the middleman, the participants had an opportunity to use their research on a wide range of subjects to illustrate the extent to which the concept could be applied to many aspects of Indonesian history. The essays by Kuitenbrouwer, Sutherland, Gaastra, and van Doorn make interesting contributions to the debate, and those by Drooglever. Noordholt, and de Jonge, in particular, demonstrate how the concept can be usefully employed in considering the place of particular individuals or groups in the Indonesian society of their time. But, in general, although the papers provide a spectrum of interesting research and ideas, the volume as a whole does not cast much new light on how the brokerage concept widens an understanding of Indonesian history. Not included are any of the discussions stimulated by the papers, nor is there any indication that, after the conference, the authors revised their ideas or manuscripts in the light of these discussions. Some concluding remarks summarizing the findings of the conference and attempting to draw the papers together would have added considerably to the book's value.

One cannot end such a review without a plea for more careful proofreading before such volumes appear in print. Even making allowances for the fact that these papers are in the native language of neither the Dutch nor Indonesian participants,

25. Tengku Luckman Sinar, S.H., "The Development of the Chinese Coolies in East Sumatra. From Middlemen into Economic Magnates."

26. "Middlemen and Commercialization: The Tobacco Traders on the Island of Madura." 
one must protest that not only are there an excessive number of typographical errors, but that these (particularly the inaccurate dates--see for example p. 196) on occasion make it impossible to understand the point the authors are attempting to make. 